\title{
Faktor Penentu Tarif Pajak Efektif Pada Perusahaan Kesehatan: Sebelum dan Saat Covid-19
}

\author{
Anindita Dresti Pinastika ${ }^{1}$ dan Ferry Irawan ${ }^{2}$ \\ ${ }^{1)}$ Direktorat Jenderal Pajak \\ ${ }^{2)}$ Politeknik Keuangan Negara STAN \\ Email Address: \\ 1401190170.anindita@gmail.com, ferry.irawan@pknstan.ac.id
}

\begin{abstract}
The pandemic of Covid-19 had attacked and contribute to the Indonesia' economics negatively. State tax revenues could not be achieved given the restrictions on activities that were intensified to prevent the spread of virus. Incentives issued by the government are one of the factors causing the decline in state revenues, one of which is in the form of lowering corporate tax rates. The effective tax rate used in measuring corporate tax management is tested with related-parties transaction, profitability, leverage, and ownership structure variables. The effect of this variable is then compared in 2019 and 2020 to observe whether there is a difference before and during the pandemic. The research was conducted on health sector companiesas a sector that was positively affected by the pandemic. The results of the study show that leverage has an effect on the effective tax rate (ETR) in 2020 while ownership structure has an effect on the ETR in 2019. The effective tax rate of health sector companies, which allegedly decreased due to incentives from the government, has actually increased during the pandemic.
\end{abstract}

Keywords:effective tax rate, pandemic, Covid-19, related parties, profitability, leverage, ownership structure.

Abstrak:Pandemi Covid-19 yang menyerang memberikan dampak buruk terhadapperekonomian di Indonesia. Penerimaan pajak negara tidak dapat tercapai mengingatpembatasan kegiatan yang digiatkan untuk mencegah penyebaran virus. Insentif yangditerbitkan pemerintah menjadi faktor penyebab turunnya penerimaan negara, salahsatunya dalam bentuk penurunan tarif pajak badan. Tarif pajak efektif yang digunakandalam mengukur pengelolaan pajak perusahaan diuji dengan variabel transaksihubungan istimewa, profitabilitas, leverage, dan struktur kepemilikan. Pengaruhvariabel ini dibandingkan antara tahun 2019 dan 2020 dan diobservasi apakah adaperbedaan sebelum dan saat pandemi. Penelitian dilakukan terhadap perusahaan sectorkesehatan sebagai sektor yang terdampak positif saat pandemi. Hasil penelitianmemperlihatkan bahwa leverage berpengaruh terhadap tarif pajak efektif pada tahun2020 dan struktur kepemilikan berpengaruh terhadap tarif pajak efektif pada tahun2019. Tarif pajak efektif perusahaan sektor kesehatan yang diduga turun akibat insentifdari pemerintah justru mengalami peningkatan pada saat pandemi.

Kata kunci:tarif pajak efektif, pandemi, Covid-19, hubungan istimewa, profitabilitas, leverage, struktur kepemilikan. 


\section{PENDAHULUAN}

Virus Covid-19 yang terdeteksi pertama kali di Wuhan, Tiongkok pada akhir tahun 2019 telah menyebar dan menjangkiti masyarakat global. Kasus virus Covid-19 pertamadi Indonesia ditemukan pada tanggal 2 Maret 2020 berdasarkan pemberitaan Biro Pers, Media, dan Informasi Sekretariat Presiden. Transmisi penularan yang bersifat airborne begitu cepat menyebar sehingga dideklarasi oleh World Health Organization (WHO) sebagai pandemi pada Maret 2020. Kasus terkonfirmasi penularan virus telah mencapai angka lebih dari 170 juta jiwa dan menyebabkan lebih dari 3,7 juta kematian di seluruh dunia per Juni 2021 (World Health Organization, n.d.).

Pandemi Covid-19 berdampak besar terhadap kehidupan masyarakat. Pembatasan sosial yang digiatkan guna menekan penyebaran virus menjadi penyebab peniadaan berbagai kegiatan masyarakat. Indonesia merupakan salah satu negara terdampak pandemidengan jumlah terkonfirmasi Covid-19 lebih dari 1,7 juta kasus dan jumlah kematian hingga 50 ribu jiwa (Satuan Tugas Penanganan Covid-19, n.d.). (Badan Pusat Statistik, 2020) juga melaporkan anjloknya produk domestik bruto (PDB) sebesar minus 3,49\% pada kuartal III-2020 yang menyebabkan Indonesia resmi menghadapi resesi ekonomi. Kurva terkonfirmasi positif Covid-19 belum kunjung landai sehingga situasi belum kondusif untuk kembali beraktivitas seperti sediakala. Hal ini berdampak negatif terhadap bisnis dan perusahaan di Indonesia dan menyebabkan keadaan ekonomi juga belum membaik.

Covid-19 telah berkontribusi terhadap penurunan pendapatan dan kerugian pada berbagai macam sektor usaha. Asian Development Bank (ADB) dalam Sambuari et al. 2020) menyampaikan bahwa kerugian ekonomi global sebesar US $\$ 347$ miliar atau setara Rp4.944 triliun telah disebabkan oleh virus ini. Deklinasi pendapatan dantimbulnya beban baru yang diperlukan untuk menjaga protokol kesehatan menjadi faktor berkurangnya pendapatan usaha. Kerugian dan penurunan pendapatan yang diderita perusahaan di Indonesia juga berdampak pada penerimaan pajak negara. Kerugian tersebutberdampak pada penurunan penghasilan yang dapat dikenai pajak atau penghasilan kena pajak (PKP). Kendati potensi penerimaan pajak menurun, pemerintah menerbitkan kebijakan insentif pajak pertambahan nilai (PPN) dan pajak penghasilan (PPh) pasal 22 demi mempertahankan dan mendukung keberlanjutan perekonomian negara.

Kemunculan pandemi menjadi faktor penurunan penerimaan pajak dan tidak tercapainya target penerimaan pajak. Penurunan penerimaan pajak disebabkan salah satunya oleh pengurangan tarif pajak penghasilan wajib pajak badan secara bertahap dari 22\% sampai 20\% pada tahun 2022 yang diatur Peraturan Pemerintah Pengganti UndangUndang Republik Indonesia Nomor 1 Tahun 2020 tentang Kebijakan Keuangan Negara dan Stabilitas Sistem Keuangan Untuk Penanganan Pandemi Corona Virus Disease 2019 (Covid-19) dan/atau dalam Rangka Menghadapi Ancaman yang Membahayakan Perekonomian Nasional dan/atau Stabilitas Sistem Keuangan. Pemerintah lebih dahulu memproritaskan pemulihan untuk keberlanjutan ekonomi di masa yang akan datang. Aturan ini diharapkan dapat membantu perusahaan yang kegiatan operasionalnya terhambat pandemi. Salah satu fokus insentif ini adalah industri farmasi produksi vaksin atau obat yang berperan dalam menyokong kebutuhan kesehatan untuk penanganan pandemi. Penurunan tarif pajak penghasilan badan yang diatur pada Perpu Nomor 1 Tahun 2020 berdampak pada penurunan penerimaan negara tahun 2020 sebesar negatif 19,71\% 
jika dibandingkan dengan tahun 2019 (APBN 2020).

Penurunan tarif pajak yang diterapkan oleh pemerintah berpengaruh terhadap beban pajak yang dibayarkan perusahaan. Manajemen pajak yang umum dinilai dengan tarif pajak efektifmenjadi tolak ukur apakah perusahaan telah mengelola beban pajak secara efektif dan efisien. Tarif pajak efektif mengukur beban pajak penghasilan dengan penghasilan laba bersih sebelum pajak. Persentase tarif yang tinggi dapat menimbulkan pertanyaan bagaimana efektivitas pengelolaan pajak yang dilakukan perusahaan (Nilasari dan Setiawan, 2019).

Tarif pajak efektif (TPE) yang diduga menurun akibat berkurangnya aktivitas operasional karena pandemi tidak terjadi di seluruh sektor usaha. Jenis sektor seperti farmasi dan kesehatan mengalami fluktuasi harga saham.Kebutuhan obat-obatan, alat kesehatan, dan vaksin untuk mencegah penyebaran wabah menjadi faktor meningkatnya pendapatan sektor kesehatan. Data dari Bursa Efek Indonesia menunjukkan nilai saham perusahaan sektor kesehatan cenderung stabil bahkan pernah mengalahkan nilai Indeks Harga Saham Gabungan (IHSG) pada Oktober 2020.

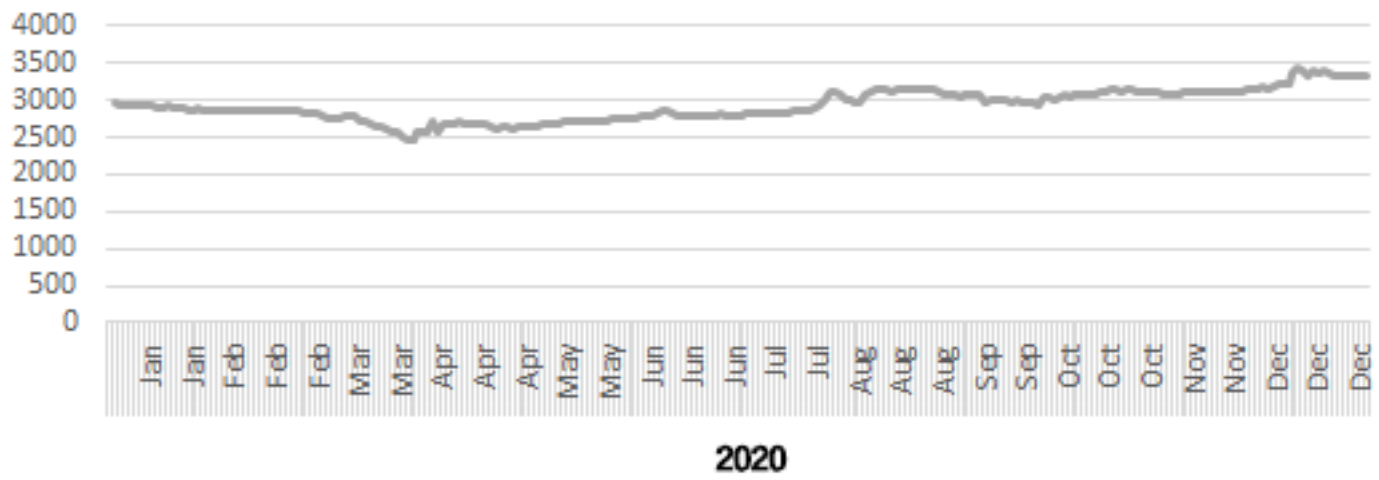

Gambar 1. Grafik Rata-rata Harga Saham Perusahaan Sektor Kesehatan Tahun 2020

Gambar 1 menampilkan data perusahaan yang beroperasi pada sektor kesehatan yang baru dikategorikan sebagai IDXHealth oleh Bursa Efek Indonesia pada Februari 2021. Hadirnya perusahaan baru yang melakukan initial public offering (IPO) seperti Diagnos Laboratorium Utama (DGNS) dan Soho Global Health (SOHO) juga menjadi indikasi perusahaan sektor kesehatan memiliki daya tarik bagi investor. Hal ini menjadi perhatian bahwa dalam kelamnya masa pandemi, perusahaan yang bergerak di bidang kesehatan memiliki potensi untuk bertumbuh dan meningkatkan pendapatannya.

Pengurangan biaya juga dapat berperan dalam memaksimalkan profit. Reduksi biaya dalam rangka peningkatan laba memiliki berbagai bentuk seperti efisiensi biaya, penggunaan metode depresiasi yang lebih efektif, pemilihan distributor dengan harga bersaing, dan pemanfaatan anak atau induk perusahaan yang memiliki hubungan istimewa. Pihak yang memiliki hubungan istimewa dapat diandalkan sebagai alternatif dalam melakukan transaksi karena mereka dapat memanfaatkan transfer pricing yang tidak memenuhi karakteristik arm's length principle. Pengurangan aktivitas operasional akibat pandemi menyebabkan perusahaan perlu lebih berhati-hati dalam memilih rekanan, kreditur serta debitur yang memiliki sustainability tinggi. 
Transaksi dengan pihak yang memiliki hubungan istimewa dapat menjadi preferensi dalam berbisnis agar kegiatan operasional tetap berjalan lancar selama pandemi. Berdasarkan PSAK 7 tentang Pengungkapan Pihak-pihak Berelasi yang diadopsi dari IAS 24 tentang Related Party Disclosures, laporan keuangan wajib mengungkapkan dan mengidentifikasi transaksi yang dilakukan dengan pihak-pihak berelasi terlepas dari ada tidaknya harga yang dibebankan. Pihak-pihak berelasi serta transaksi yang terjadi dengan pihak tersebut harus diungkapkan sebagai syarat terpenuhinya standar laporan keuangan. Selain pengungkapan pihak-pihak berelasi berdasarkan PSAK, Direktorat Jenderal Pajak juga mengatur terkait transaksi hubungan istimewa. Undang-Undang Republik Indonesia Nomor 36 Tahun 2008 tentang Perubahan Undang-Undang Nomor 7 Tahun 1984 (UU $\mathrm{PPh}$ ) Pasal 18 huruf (4) menyatakan adanya hubungan istimewa apabila wajib pajak memiliki penyertaan baik langsung maupun tidak langsung dengan penyertaan terendah sebesar 25\%, menguasai wajib pajak lainnya baik secara langsung dan/atau tidak langsung, dan terdapat hubungan keluarga sedarah atau semenda dalam garis keturunan lurus atau ke samping satu derajat.

Laba perusahaan dapat terdongkrak naik dengan transaksi hubungan istimewa(Indradi dan Setyahadi,2019). Transaksi-transaksi tersebut memiliki nilai rendah atau tinggi sesuai kebutuhan perusahaan sehingga penghematan biaya dapat dilakukan. Kontrak jangka panjang dengan pihak yang memiliki hubungan istimewa juga dapat dilakukan dengan kesepakatan harga yang stabil dan tidak perlu dikhawatirkan akan berubah di masa depan. Pada penelitian ini, transaksi hubungan istimewa menjadi salah satu fokus observasi sebagai alternatif perusahaan dalam mengurangi atau menambah beban operasional perusahaan dalam mengantisipasi keadaan pandemi yang belum membaik. Transaksi hubungan istimewa juga dapat digunakan sebagai pengurang penghasilan yang dikenai pajak seperti pembayaran bunga dan penjualan menggunakan transfer pricing.

(Oktavia et al.. 2012)menyatakan bahwa kerugian dapat diderita pemilik saham minoritas akibat transaksi dengan pihak-pihak yang memiliki hubungan istimewa apabila ada permainan harga transfer pricing yang menjatuhkan harga saham. Hal ini dapat dihindari dengan pengungkapan pihak berelasi dan transaksi terkait dengan benar. Pemegang saham memiliki peranan besar dalam pengambilan keputusan. Kekuasaan pemegang saham bergantung pada jumlah kepemilikan lembar saham perusahaan. Semakin banyak jumlah lembar saham yang dimiliki maka semakin besar pengaruh dan kekuasaannya terhadap perusahaan.

Struktur kepemilikan perusahaan yaitu kepemilikan saham perusahaan yang diukur menggunakan jumlah persentase saham yang dimiliki (Syamsuddin dan Trisni, 2019).Konflik antara manajemen dengan pemegang saham dapat diminimalisasi dengan kepemilikan saham oleh manajemen yang menjadi penyelaras tujuan antar kedua belah pihak. Manajemen yang menjadi bagian pemilik perusahaan dapat mengurangi biaya keagenan. Profitabilitas perusahaan merupakan salah satu aspek yang dipertimbangkan dalam menentukan investasi. Perusahaan dengan profitabilitas yang stabil di masa pandemi seperti perusahaan yang bergerak di sector kesehatanmenarik minat investor karena kebutuhan terkait produk dan jasa kesehatan akan selalu ada dan terus berlanjut. Profitabilitas yang baik juga menjadi salah satu dasar pertimbangan kualitas kinerja perusahaan. 
Pendapatan tinggi diharapkan dapat menjaga sustainability perusahaan. Maksimalisasi profit juga dapat dicapai dengan pengurangan beban. Salah satu bentuk pengurangan beban didapatkan dari pembayaran bunga yang berimbas terhadap penghasilan kena pajak. Pengenaan bunga berkaitan erat dengan kewajiban perusahaan. Semakin tinggi bunga maka semakin besar pula pengurang penghasilan kena pajak. Akan tetapi, penggunaan utang yang tidak terkendali dapatmembahayakan perusahaan. Utang diukur dengan tingkat utang untuk mengetahui kemampuan perusahaan dalam melunasi utang dengan modal yang dimiliki. Penelitian yang dilakukan oleh (Indradi dan Setyahadi, 2019)menyampaikan bahwa transaksi hubungan istimewa yang dipresentasikan dalam bentuk utang dan piutang hubungan istimewa memiliki pengaruh terhadap tarif pajak efektif.

Berbagai faktor tersebut memiliki pengaruh terhadap tarif pajak efektif dan telah dilakukan penelitian dengan variabel yang berbeda-beda. Penelitian sebelumnya rata-rata menguji perusahaan sektor manufaktur dan belum merambah ke sektor lain seperti sektor kesehatan yang menjadi fokus penulis. Berdasarkan penjelasan tersebut, penulis memutuskan meneliti faktor-faktor yang memengaruhi tarif pajak efektif pada perusahaan sektor kesehatan dan perbandingannya dari sebelum dan saat pandemi Covid-19.

\section{KAJIAN TEORI}

Teori agensi adalah kontrak principal yang menyewa orang lain (agen) untuk melakukan pendelegasian wewenang dan pengambilan keputusan atas nama principal menurut Jensen dan Meckling dalam(Susilawaty, 2020). Pelimpahan wewenang yang dilakukan pemilik kepada manajer memberikan hak kepada manajer tersebut untuk membuat keputusan bisnis sesuai kepentingan principal. Tindakan ini dapat menimbulkan perbedaan pendapat antara manajer selaku penerima hak dengan keinginan pemilik yaitu konflik keagenan. Teori keagenan mengimplikasi kemungkinan terjadinya sikap oportunistis agen sehingga mereka melakukan tindakan-tindakan yang tidak sesuai tujuan principal seperti income smoothing, melaporkan pendapatan yang berbeda dengan sebenarnya, melaporkan hasil penjualan yang rendah, dan sebagainya. Hal itu terjadi karena perbedaan tujuan manajer dan pemilik. Manajer acap kali mengambil keputusan yang mengutamakan kepentingan manajer sendiri dan bukan kepentingan pemilik saham, sehingga melahirkan konflik keagenan.

Teori keagenan mengemukakan bahwa pengawasan dan pengendalian tindakan manajemen bergantung pada banyaknya jumlah dewan komisaris independen, semakin banyak jumlahnya maka akan semakin baik untuk perusahaan. Konflik keagenan dapat ditekan dengan memberikan sebagian kepemilikan kepada manajer untuk menyesuaikan tujuan manajer dengan pemilik. Variabel bebas yang digunakan dalam penelitian ini menggunakan kepemilikan manajerial dan kepemilikan publik yang memengaruhi pembuatan keputusan perusahaan, termasuk keputusan terkait perpajakan. Kepemilikan manajerial menjadi salah satu penyelesaian biaya keagenan. Teori agensi digunakan untuk menyelaraskan kepentingan agen dengan principal agar memiliki satu tujuan yang sama yaitu untuk mendapatkan return sebesar-besarnya (Syamsuddin dan Trisni, 2019).

Dewan komisaris sebagai susunan kepemilikan perseroan merupakan salah satu dari bagian perseroan yang memiliki tugas pengawasan dan bertugas memberikan nasihat kepada dewan direksi sesuai susunan anggaran dasar perusahaan. Dewan komisaris 
disusun oleh komisaris independen, manajerial, institusional, publik serta pemerintah. Komisaris independen adalah anggota komisaris yang tidak memiliki afiliasi dengan anggota komisaris lainnya, pemilik saham pengendali, dewan direksi ataupun pemilik saham lainya sehingga tidak memengaruhi tingkat independennya(Syamsuddin dan Trisni, 2019).

Kepemilikan manajerial sebagai salah satu bagian dari struktur kepemilikan perusahaan merupakan kepemilikan yang dikuasai oleh manajemen baik direksi, komisaris maupun karyawan (Syamsuddin dan Trisni, 2019). Saham yang dimiliki oleh manajemen akan mengurangi konflik keagenan karena kepemilikan tersebut dapat memotivasi manajemen untuk meningkatkan kinerjanya lantaran tujuan manajer menjadi selaras dengan pemilik saham. Kepemilikan manajerial diukur dengan memperhitungkan proporsi kepemilikan saham yang dimiliki manajer, direksi, komisaris, dan pihak manajerial lainnya yang secara aktif berpartisipasi dalam pengambilan keputusan perusahaan (Sabrinna, 2019). dan perbandingannya dari sebelum dan saat pandemi Covid-19.

Hubungan istimewa juga digunakan sebagai kajian teori dengan berdasar pada Pasal 18 ayat (4) UU PPh dan Peraturan Menteri Keuangan Nomor 22/PMK.03/2020 tentang Tata Cara Pelaksanaan Kesepakatan Harga Transfer (Advance Pricing Agreement) pada pasal 4.

(Fransiska dan Lestari, 2014) menyatakan bahwa transaksi hubungan istimewa yakni ketika perusahaan bertransaksi dengan pihak yang memiliki hubungan istimewa dengan perusahaan. Transaksi yang dapat meningkatkan efisiensi operasional perusahaan dan transaksi yang bersifat merugikan merupakan dua sudut pandang pengaruh transaksi dengan pihak yang memiliki hubungan istimewa terhadap kinerja keuangan perusahaan.

Menurut(Yudawirawan et al., 2021), pelaku usaha akan berusaha melakukan penyesuaian agar dapat bersaing dengan mengatur proses produksi dalam divisi juga menerapkan strategi yang menguntungkan perusahaan. Pembentukan divisi atau anak perusahaan dengan afiliasi hubungan istimewa bertujuan untuk memaksimalkan kegiatan produksi. Pihak-pihak terkait yang melakukan transaksi hubungan istimewa dapat merekayasa harga transaksi penjualan maupun pembelian di luar harga pasar atau harga wajar. Hubungan istimewa menjadi ancaman bagi Direktorat Jenderal Pajak (DJP) karena harga transfer yang tidak wajar akan menyebabkan penurunan penghasilan perusahaan yang dapat dikenai pajak. Laba perusahaan yang rendah akan berimbas terhadap berkurangnya beban pajak yang dibayar perusahaan.

Transfer pricing.Sebagai pemanfaatan harga yang umum digunakan dalam transaksi hubungan istimewa adalah upaya penetapan harga transaksi yang dilakukan dengan pihak berafiliasi, berdomisili di yurisdiksi pajak yang berbeda dengan tujuan untuk mengurangi beban pajak yang ditanggung oleh perusahaan multinasional tersebut (Darussalam et al., 2013). The Organisation for Economic Co-operation and Development (OECD) menyatakan bahwa transfer pricing harus didasarkan pada arm's length principle, yaitu prinsip adanya rentang angka yang bisa diterima untuk menetapkan apakah kondisi transaksi terkendali itu wajar dan diukur baik dengan penerapan metode penetapan harga transfer yang sama ke beberapa data sebanding atau dari penerapan metode penetapan harga transfer yang berbeda. Article 9 OECD menjelaskan apabila ada laba yang muncul akibat transaksi yang tidak wajar dan tidak sebanding maka dapat dikenakan pajak sesuai ketentuan yang berlaku. 
Transfer pricing adalah harga pada jasa atau barang yang ditransfer dari satu bagian ke bagian lain dalam satu perusahaan yang sama atau antar perusahaan berbeda yang memiliki hubungan istimewa (Pertiwi et al., 2018). Berdasarkan Indradi dan Setyahadi (2019), transaksi hubungan istimewa adalah transaksi antar pihak-pihak yang memiliki kemampuan mengendalikan pihak lain karena adanya kepemilikan langsung, penyertaan modal, atau perjanjian. Transaksi ini dapat terjadi tidak hanya dalam satu wilayah negara tetapi juga melewati lintas batas wilayah negara.

Berdasarkan (Nilasari dan Setiawan, 2019), transaksi hubungan istimewa merupakan transaksi yang rawan mengakibatkan kerugian kepada pihak-pihak tertentu seperti pemerintah. Walaupun pada dasarnya tidak ada larangan bertransaksi dengan pihak yang memiliki hubungan istimewa, namun sifat terikat antar perusahaan bisa menjadi kesempatan transaksi dengan rekayasa harga di luar kewajaran. Harga tidak wajar inilah yang menjadi sorotan DJP karena harga tersebut dapat digunakan untuk melakukan penghindaran pajak. Deteksi pemanfaatan harga tidak wajar ini dapat dilakukan dengan memeriksa tarif pajak efektif perusahaan apakah lumrah dan seimbang dengan laporan keuangan yang telah dilapaorkan.

Tarif pajak efektif adalah persentase beban pajak penghasilan badan yang dibayarkan perusahaan dibagi dengan penghasilan sebelum dikenai pajak. (Indradi dan Setyahadi, 2019) menyatakan bahwa tarif pajak efektif merupakan perbandingan antara pembayaran beban pajak dengan penghasilan sebelum pajak perusahaan. Rasio tarif pajak efektif tersebut dapat mempresentasikan efektivitas pembayaran pajak perusahaan. Pembuat keputusan dan pihak-pihak berkepentingan juga menggunakan tarif pajak efektif sebagai salah satu acuan untuk membuat kebijakan terkait manajemen pajak perusahaan.

Tarif pajak efektif merupakan salah satu bentuk penilaian seberapa baik perusahaan dalam mengatur dan mengelola perpajakannya (Sarwoasih dan Indarto, 2018). Pernyataan tersebut selaras dengan penelitian (Syamsuddin dan Trisni, 2019) yang mengemukakan bahwa tarif pajak efektif dapat dikategorikan sebagai ukuran perencanaan pajak yang efektif. Perusahaan mampu mendapatkan hasil terbaik dengan mengurangi biaya pengeluaran pajak seperti menggunakan metode akuntansi yang bisa menurunkan beban pajak secara efektif.

Manajemen pajak merupakan upaya yang dilakukan perusahaan dalam mengelola kewajiban perpajakannya secara efektif dan efisien. (Juliani, 2019) mengemukakan bahwa manajemen pajak yang dilakukan perusahaan ada kaitannya dengan peranan manajemen seperti perencanaan pajak (tax planning) dengan memanfaatkan peluang pada peraturan perpajakan yang ada untuk keuntungan perusahaan. Tarif pajak efektif perusahaan menjadi acuan bagaimana manajemen perusahaan bertindak untuk dapat menekan kewajiban perpajakannya. Tarif pajak efektif yang tinggi dapat menjadi cerminan kurang maksimalnya perusahaan dalam memanfaatkan insentif pajak yang ada. Jika perusahaan dapat memanfaatkan insentif tersebut dengan baik, maka perusahaan dapat menurunkan persentase beban pajak yang dibayarkan.

Perusahaan yang membayar pajak dengan tarif lebih tinggi atau rendah (Soepriyanto, 2011) dapat terjadi karena terdapat perbedaan perlakuan pencatatan akuntansi dan pencatatan pajak yang menyebabkan munculnya koreksi fiskal. Beberapa faktor lain yang dipertimbangkan sebagai objek observasi adalah profitabilitas dan leverage.

Profitabilitas merupakan ukuran yang digunakan perusahaan untuk menilai efisiensi 
penggunaan modal dengan membandingkan laba yang dihasilkan dengan modal yang digunakan (Darmadi dan Zulaikha, 2013). Berdasarkan (Juliani, 2019), manajemen dapat dianggap sukses dalam memaksimalkan sumber daya ketika perusahaan memperoleh jumlah pendapatan lebih tinggi dibandingkan dengan biaya yang dikeluarkan untuk menghasilkan pendapatan. (Indrawati, 2020)menyimpulkan bahwa rasio profitabilitas dapat menggambarkan kemampuan aset yang dimiliki perusahaan dalam menghasilkan laba. Profitabilitas yang diukur dengan return on assets (ROA) dapat mencerminkan tingkat efektifitas suatu perusahaan dalam memanfaatkan aset yang dimiliki demi mendapat pendapatan sesuai dengan pengendaliannya.

Leverage digunakan untuk menjabarkan tingkat risiko perusahaan dalam membiayai perusahaan yang diukur dengan membandingkan total utang dengan total ekuitas(Pertiwi et al., 2018). (Indradi dan Setyahadi, 2019) menyatakan bahwa leverage dihitung dengan rasio yang menggambarkan berapa banyak aset perusahaan dapat membayar utang yang ditanggung oleh perusahaan. Rasio ini memberikan perkiraan sejauh mana perusahaan sanggup membayar seluruh kewajibannya.

Berdasarkan kajian teori yang telah dipaparkan, diambil beberapa hipotesis yang memengaruhi tarif pajak efektif sebagai variabel terikat dalam penelitian ini. Hipotesis dijabarkan sebagai berikut:

H1: Piutang hubungan istimewa berpengaruh signifikan positif terhadap tarif pajak efektif.

H2: Utang hubungan istimewa berpengaruh signifikan negatif terhadap tarif pajak efektif.

Pandemi menyebabkan perusahaan harus bertahan dalam keadaan kinerja operasional yang tidak optimal akibat pembatasan aktivitas. Risiko penurunan kegiatan operasional perusahaan ini menyebabkan manajemen harus lebih lebih hati-hati dalam bertransaksi. Karena itu, diduga bahwa transaksi dengan pihak dengan hubungan istimewa lebih dapat dipercaya dan menjadi salah satu alternatif untuk mempertahankan operasional perusahaan.

(Fransiska dan Lestari, 2014)mengutarakan bahwa transaksi hubungan istimewa dapat dimanfaatkan untuk mengurangi beban, waktu transaksi juga risiko di masa depan. Transaksi hubungan istimewa dipandang efisien dan berpengaruh positif terhadap pencapaian kinerja perusahaan. Akan tetapi, transaksi hubungan istimewa bisa juga bersifat tidak menguntungkan. Contohnya adalah pembelian yang dilakukan untuk menguntungkan satu pihak saja seperti perusahaan pengendali, hal ini dapat terjadi sebab kekuasaan dalam mengatur kebijakan dimiliki oleh perusahaan pengendali.

(Indradi dan Setyahadi, 2019) menyampaikan piutang hubungan istimewa sebagai proksi transaksi hubungan istimewa memiliki pengaruh atas tarif pajak efektif sedangkan utang hubungan istimewa berpengaruh negatif terhadap tarif pajak efektif. Penelitian ini menunjukkan semakin tinggi nilai utang hubungan istimewa maka semakin rendah pula tarif pajak efektif. Temuan ini mengindikasikan pembayaran pajak perusahaan dapat dipengaruhi transaksi hubungan istimewa. Berdasarkan penjelasan di atas, ditentukan dua hipotesis transaksi hubungan istimewa yang berpengaruh terhadap tarif pajak efektif.

H3: Profitabilitas berpengaruh positif terhadap tarif pajak efektif. 
Profitabilitas memegang peranan penting dalam keberlangsungan perusahaan, karena pada umumnya profit merupakan tujuan awal perusahaan. (Kim dan Limpaphayom, 1998)menyatakan bahwa profitabilitas memiliki potensial dalam memengaruhi tarif pajak efektif. Profitabilitas secara umum dapat meningkatkan atau menurunkan tarif pajak karena pengenaan pajak didasari dari profitabilitas itu sendiri. Profitabilitas yang tinggi maka umumnya pendapatan yang dapat dikenakan pajak juga tinggi. (Gita et al., 2021) menyatakan bahwa profitabilitas memberikan pengaruh signifikan positif terhadap tarif pajak efektif. (Sarwoasih dan Indarto, 2018) menyampaikan bahwa ROA sebagai rasio profitabilitas merupakan salah satu indikator dalam pencapaian profit perusahaan. Laba yang tinggi akan menyebabkan tarif pajak efektif turut meningkat. Hasil penelitian (Sarwoasih dan Indarto, 2018) menyatakan bahwa ROA juga berpengaruh signifikan positif terhadap tarif pajak efektif.

Profitabilitas seyogyanya berkaitan erat dengan tarif pajak efektif karena TPE itu sendiri dihitung berdasarkan beban pajak penghasilan yang didapat dari penghasilan kena pajak sebagai bentuk dari profitabilitas itu sendiri. (Erawati dan Jega, 2019) menyampaikan bahwa hubungan antara variabel profitabilitas yang diproksikan dengan ROA dan tarif pajak efektif dipengaruhi oleh perusahaan yang melakukan tax burden dengan menekan pajak demi mendapatkan laba atau penghasilan kena pajak yang tinggi. Semakin besar nilai ROA, maka nilai laba bersihnya juga besar. Jumlah laba bersih yang besar ini akan dikelola perusahaan untuk mendapatkan penghasilan yang tinggi. ROA yang tinggi menunjukkan bahwa performa keuangan tersebut bagus. Selain untuk mendapatkan laba bersih, perusahaan juga ingin laba bersih yang tinggi tersebut dapat menarik para investor untuk berinvestasi pada perusahaan. Dalam hal ini, dapat disimpulkan semakin tinggi nilai ROA, maka semakin tinggi pula tarif pajak efektif perusahaan.

H4: Leverage berpengaruh negatif terhadap tarif pajak efektif.

Penelitian yang dilakukan oleh (Pertiwi et al., 2012), (Erawati dan Jega, 2019) dan (Nindita et al., 2021)memberikan hasil yang serupa yaitu leverage berpengaruh positif terhadap tarif pajak efektif. Hasil ini perlu diteliti lebih lanjut mengingat tingkat utang yang semakin tinggi seharusnya akan meningkatkan biaya bunga yang dapat digunakan sebagai pengurang penghasilan kena pajak.

H5: Struktur kepemilikan manajerial berpengaruh negatif terhadap tarif pajak efektif.

H6: Struktur kepemilikan publik berpengaruh positif terhadap tarif pajak efektif.

Struktur kepemilikan perusahaan terdiri dari berbagai pihak termasuk bagian manajemen perusahaan itu sendiri. (Juliani, 2019)menyatakan bahwa dewan komisaris yang dimiliki pihak independen tidak berpengaruh terhadap tarif pajak efektif. Lain halnya dengan (Nilasari dan Setiawan, 2019) yang menyatakan bahwa komisaris independen berpengaruh positif terhadap tarif pajak efektif. (Syamsuddin dan Trisni, 2019) meneliti bahwa tidak terdapat pengaruh komisaris independen terhadap tarif pajak efektif karena komisaris independen dianggap ada hanya untuk memenuhi ketentuan peraturan dan tidak berdampak terhadap kebijakan perusahaan. Masih berdasarkan pada penelitian yang sama, 
kepemilikan manajerial juga tidak berpengaruh terhadap tarif pajak efektif dikarenakan rata-rata persentase kepemilikan saham manajerial relatif kecil yang mengindikasi bahwa perusahaan dikuasai pemegang saham lainnya. Manajer yang tidak termasuk dalam kepemilikan perusahaan, cenderung tidak temotivasi untuk meningkatkan kinerjanya terutama dalam pengelolaan pajak.

Perencanaan pajak yang baik dapat dilakukan dengan pengawasan jumlah komisaris yang besar (Juliani, 2019). Namun pada penelitian perusahaan industri sektor barang konsumsi, jumlah komisaris independen tidak berpengaruh terhadap tarif pajak efektif. Perbedaan ini menjadi dasar untuk menentukan struktur kepemilikan sebagai variabel independen yang berkaitan dengan variabel dependen tarif pajak efektif. Semakin tinggi struktur kepemilikan manajerial maka diduga akan meningkatkan performa perusahaan itu sendiri.

H7: Tarif pajak efektif di tahun 2020 lebih rendah dibandingkan tahun 2019.

Dalam penelitian juga akan dilakukan perbandingan pengaruh variabel-variabel yang telah disebutkan di atas terhadap tarif pajak efektif pada tahun 2020 saat masa pandemi dan tahun 2019 saat sebelum pandemi terjadi. Perbandingan dilakukan mengingat dampak pandemi Covid-19 yang begitu masif terhadap perekonomi baik secara global maupun nasional. Perusahaan sektor kesehatan yang dijadikan fokus dalam objek penelitian juga merupakan sektor terdampak yang memiliki potensi pertumbuhan sangat luas. Perekonomian yang terpuruk serta insentif yang digalakkan pemerintah untuk menyokongnya menjadi dugaan tarif pajak efektif rendah dibandingkan tahun sebelumnya. Karena itu hipotesis terakhir adalah:

\section{METODELOGI}

Tarif pajak efektif sebagai variabel terikat diuji dan diamati dengan transaksi hubungan istimewa, profitabilitas, leverage, serta struktur kepemilikan sebagai variabel bebas yang memengaruhinya. Penulis menggunakan model kerangka dengan mengacu pada penelitian sebelumnya yang diuji di tahun 2020 dan 2019.

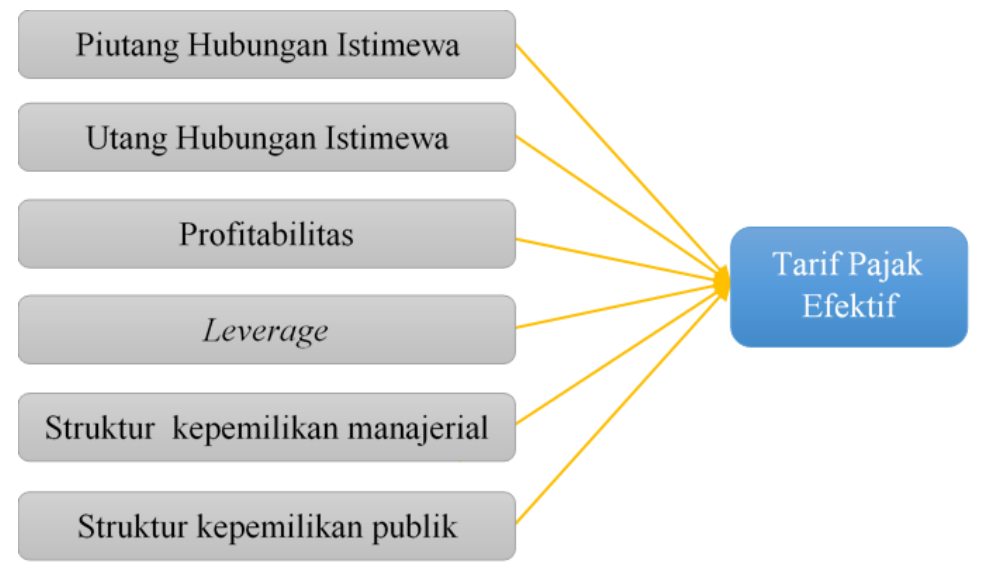

Gambar 2.Model Penelitian 
Penelitian menggunakan metode kuantitatif dengan memanfaatkan sumber data sekunder. Penelitian juga dilakukan dengan membandingkan data kuantitatif pada tahun yang berbeda yaitu tahun 2020 dan 2019. Periode ini dipilih untuk melihat perbedaan masa pandemi dan masa normal saat sebelum pandemi. Data yang diteliti adalah data laporan keuangan perusahaan kesehatan yang telah diterbitkan dan diaudit. Laporan keuangan bersumber dari Bursa Efek Indonesia. Penelitian ini menggunakan metode purposive sampling sebagai teknik pengambilan sampel, yaitu teknik penentuan sampel dengan pertimbangan/kriteria tertentu (Sugiyono, 2019). Kriteria-kriteria yang digunakan dalam penyusunan sampel adalah: (1) Perusahaan yang sudah terdaftar dalam sektor kesehatan Bursa Efek Indonesia di tahun 2020. (2) Perusahaan yang menerbitkan laporan keuangan tahunan tahun 2020 dan 2019. (3) Perusahaan melaporkan pendapatan atau laba positif, karena kerugian atau nilai negatif akan menimbulkan proksi yang negatif dan tidak bisa digunakan karena akan membuat data jadi bias. (4) Perusahaan yang memiliki transaksi hubungan istimewa.

Sampel yang digunakan berjumlah 17 dari populasi 24 perusahaan setelah mememnuhi kriteria yang ditentukan. Model regresi penelitian yang digunakan adalah sebagai berikut

$\mathrm{TPE}_{\mathrm{it}}=\alpha_{0}+\beta_{1}$ PiutangHI $_{\mathrm{it}}+\beta_{1} \mathrm{UtangHI}_{\mathrm{it}}+\beta_{3}$ Profitabilitas $_{\mathrm{it}}+\beta_{4}$ Leverage $_{\mathrm{it}}+$ $\beta_{4}$ Kepemilikan manajerial $_{\text {it }}+\beta_{4}$ Kepemilikan publik $_{\text {it }}+\varepsilon_{\text {it }}$

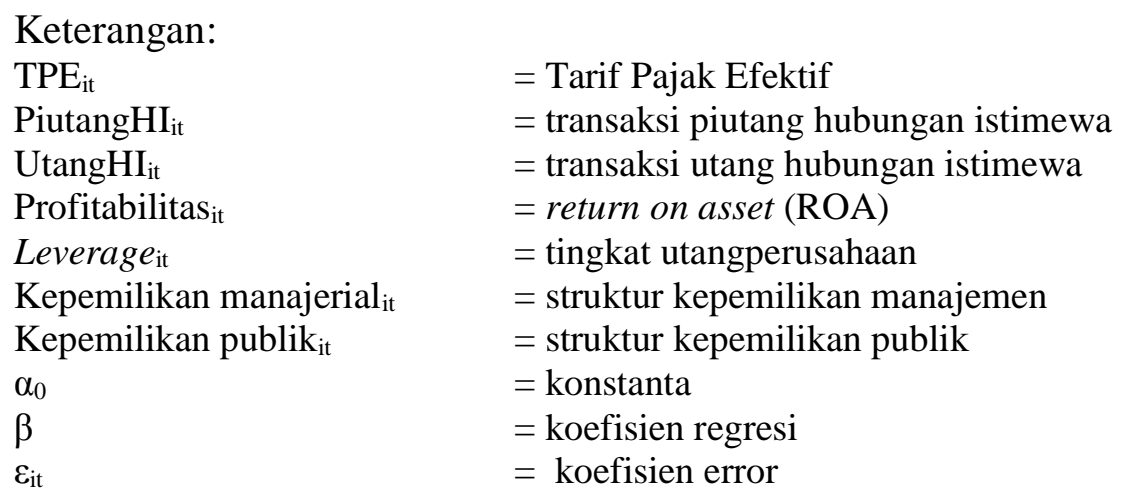

\section{HASIL UJI STATISTIK}

Berdasarkan penelitian menggunakan analisis deskriptif dan regresi, didapatkan hasil penelitian pada gambar.

Tabel 1. Analisis Statistik Deskriptif Tahun 2020

\begin{tabular}{lcrrccrr}
\hline & TPE & Piutang_HI & Utang_HI & Profit & DER & SK_Manajer & SK_Publik \\
\hline \hline Mean & 0.339487 & 0.073928 & 0.037546 & 0.104427 & 1.002543 & 0.744421 & 0.175161 \\
Median & 0.240596 & 0.015420 & 0.005681 & 0.091642 & 0.517752 & 0.816500 & 0.133500 \\
Maximum & 0.998340 & 0.430088 & 0.197598 & 0.397410 & 4.082218 & 1.000000 & 0.455600 \\
Minimum & 0.207418 & 0.000000 & 0.000000 & $1.75 E-05$ & 0.155007 & 0.000000 & 0.000000 \\
Std.Dev. & 0.226245 & 0.121241 & 0.063421 & 0.097761 & 1.066124 & 0.260027 & 0.147754 \\
Skewness & 1.951074 & 1.790173 & 1.745678 & 1.640476 & 1.823979 & -1.652595 & 0.667821
\end{tabular}




\begin{tabular}{lcccccrc} 
Kurtosis & 5.569154 & 5.365503 & 4.567712 & 5.914243 & 5.531970 & 5.203166 & 2.187441 \\
Jarque-Bera & 15.46101 & 13.04359 & 10.37516 & 13.64070 & 13.96725 & 11.17624 & 1.731304 \\
Probability & 0.000439 & 0.001471 & 0.005585 & 0.001091 & 0.000927 & 0.003742 & 0.420777 \\
Sum & 5.771281 & 1.256768 & 0.638282 & 1.775251 & 17.04322 & 12.655516 & 2.977740 \\
SumSq Dev. & 0.818992 & 0.235190 & 0.064355 & 1.775251 & 18.18592 & 1.081824 & 0.349300 \\
Observation & 17 & 17 & 17 & 17 & 17 & 17 & 17 \\
\hline
\end{tabular}

Tabel 2. Analisis Statistik Deskriptif Tahun 2019

\begin{tabular}{lcrrcrrr}
\hline \hline & TPE & Piutang_HI & Utang_HI & Profit & DER & SK_Manajer & SK_Publik \\
\hline \hline Mean & 0.264609 & 0.045347 & 0.029424 & 0.085339 & 0.928858 & 0.762471 & 0.175788 \\
Median & 0.263790 & 0.010135 & 0.006819 & 0.079461 & 0.445816 & 0.816000 & 0.133500 \\
Maximum & 0.585274 & 0.268399 & 0.199881 & 0.228836 & 4.227895 & 1.000000 & 0.430400 \\
Minimum & 0.183050 & 0.000000 & $6.52 E-05$ & 0.000866 & 0.151678 & 0.045400 & 0.000000 \\
Std.Dev. & 0.098054 & 0.071250 & 0.053527 & 0.059540 & 1.017695 & 0.253741 & 0.144446 \\
Skewness & 1.569509 & 2.034080 & 2.287696 & 0.561408 & 2.109524 & -1.668426 & 0.477423 \\
Kurtosis & 5.488610 & 6.664499 & 7.285154 & 3.181745 & 7.489428 & 5.138546 & 1.914320 \\
Jarque-Bera & 11.36635 & 21.23475 & 27.83521 & 0.916403 & 26.88503 & 11.12648 & 1.480723 \\
Probability & 0.003403 & 0.000024 & 0.000001 & 0.632420 & 0.00001 & 0.003836 & 0.476941 \\
Sum & 5.008345 & 0.770904 & 0.500211 & 1.450758 & 15.79058 & 12.96200 & 2.988400 \\
SumSq Dev. & 0.153834 & 0.081225 & 0.045842 & 0.056720 & 16.57125 & 1.030154 & 0.333834 \\
Observation & 17 & 17 & 17 & 17 & 17 & 17 & 17 \\
\hline
\end{tabular}

Tabel 3. Hasil Uji Regresi Tahun 2020

Dependent Variable: TPE

Method: Least Squares

Sample: 117

\begin{tabular}{|c|c|c|c|}
\hline Variable & Coefficient & t-Statistic & Prob. \\
\hline $\mathrm{C}$ & 0.255689 & 1.389152 & 0.1949 \\
\hline PIUTANG_HI & 0.193222 & 0.416160 & 0.6861 \\
\hline UTANG_HI & -1.014021 & -1.526000 & 0.1580 \\
\hline PROFIT & -0.726192 & -1.077725 & 0.3065 \\
\hline DER & 0.122500 & 2.339987 & 0.0413 \\
\hline SK_MANAJER & 0.129296 & 0.717512 & 0.4895 \\
\hline SK_PUBLIK & -0.203481 & -0.639995 & 0.5366 \\
\hline R-squared & 0.710770 & & \\
\hline Adjusted R-squared & 0.537231 & & \\
\hline F-statistic & 4.095752 & & \\
\hline Prob (F-statistic) & 0.024555 & & \\
\hline
\end{tabular}

Sumber: Diolah dari Aplikasi Eviews 10 
Tabel 4. Hasil Uji Regresi Tahun 2019

Dependent Variable: TPE

Method: Least Squares

Sample: 117

\begin{tabular}{crrr}
\hline \hline Variable & Coefficient & \multicolumn{1}{c}{ t-Statistic } & Prob. \\
\hline \hline C & 0.602262 & 8.014214 & 0.0000 \\
PIUTANG_HI & -0.113892 & -0.510312 & 0.6209 \\
UTANG_HI & 0.076923 & 0.238374 & 0.8164 \\
PROFIT & 0.143677 & 0.333565 & 0.7456 \\
DER & 0.012917 & 0.542448 & 0.5994 \\
SK_MANAJER & -0.314162 & -4.036191 & 0.0024 \\
SK_PUBLIK & -0.508974 & -3.935980 & 0.0028 \\
\hline \hline R-squared & 0.747061 & & \\
Adjusted R-squared & 0.595298 & & \\
F-statistic & 4.922540 & & \\
Prob (F-statistic) & 0.013570 & & \\
\hline \hline
\end{tabular}

Sumber: Diolah dari Aplikasi Eviews 10

\section{DISKUSI}

Hipotesis 1: Pengaruh piutang hubungan istimewa terhadap tarif pajak efektif. Piutang hubungan istimewa tidak berpengaruh terhadap tarif pajak efektif pada perusahaan sektor kesehatan tahun 2019 dan 2020. Dalam hal ini diduga, tarif pajak efektif dalam sektor ini memang tidak dipengaruhi transaksi hubungan sebab nilai transaksi hubungan istimewa yang tidak terlalu besar. Pada tabel 1 dan 2 dapat dilihat bahwa rata-rata transaksi piutang hubungan istimewa tahun 2020 dan 2019 masing-masing hanya sebesar 0.073928 dan 0.045347 . Nilai ini terbilang kecil jika dibandingkan dengan keseluruhan aset perusahaan. Terdapat pula perusahaan yang tidak memiliki piutang dengan hubungan istimewa, sehingga secara keseluruhan piutang hubungan istimewa tidak berpengaruh terhadap tarif pajak efektif.

Hasil penelitian sebanding dengan penelitian yang dilakukan oleh (Oktavia et al., 2012), (Nilasari dan Setiawan, 2019), dan (Nindita et al., 2021). Menurut (Nilasari dan Setiawan, 2019) adanya transaksi hubungan istimewa menyebabkan bertambahnya beban pajak yang dibayar perusahaan. Temuan ini memperkuat dugaan bahwa transaksi hubungan istimewa yang dilakukan perusahaan, berdampak negatif terhadap penerimaan perpajakan negara. Hasil regresi tahun 2019 dan 2020 memberikan koefisien yang berbeda, sehingga simpulan (Nilasari dan Setiawan, 2019) diduga sebagai salah satu faktor tidak berpengaruhnya piutang hubungan istimewa terhadap tarif pajak efektif.

Hipotesis 2: pengaruhutang hubungan istimewa terhadap tarif pajak efektif. Ratarata transaksi utang hubungan istimewa berdasarkan Tabel 1 dan 2 hanya sebesar 0.037456 dan 0.029424. Nilai ini diduga menjadi faktor tidak adanya pengaruh utang hubungan istimewa tarhadap tarif pajak efektif. Penelitian (Nindita et al., 2021) juga memberikan hasil tidak ada pengaruh utang hubungan istimewa terhadap tarif pajak 
efektif. Berbeda dengan hasil penelitian (Oktavia et al., 2012) dan (Indradi dan Setyahadi, 2019) yang menyatakan bahwa utang hubungan istimewa berpengaruh negatif terhadap tarif pajak efektif.

Namun demikian berdasarkan data Kemendagri, kegiatan operasional sektor kesehatan dan farmasi di Indonesia masih bergantung pada impor. Transaksi impor yang dilakukan oleh perusahaan farmasi ini dapat disimpulkan tidak didominasi oleh transaksi dengan pihak-pihak yang memiliki hubungan istimewa sehingga utang hubungan istimewa tidak berpengaruh terhadap TPE. Hal ini mengindikasikan dugaan bahwa hubungan istimewa memengaruhi variabel lain di luar tarif pajak efektif.

Hipotesis 3: Pengaruh profitabilitas terhadap tarif pajak efektif. Berdasarkan hasil uji hipotesis, profitabilitas pada kedua periode yang diujikan tidak memiliki pengaruh terhadap tarif pajak efektif. Profitabilitas yang diterima pada perusahaan sektor kesehatan pada masa pandemi juga berfluktuatif sehingga sulit diprediksi. Rasio profitabilitas tahun 2019 yang ditunjukkan pada Tabel 2 menunjukkan angka yang sangat kecil. Berdasarkan analisis Kemendagri, hal tersebut disebabkan lambatnya laju pertumbuhan perusahaan sektor farmasi dan kesehatan di Indonesia sebelum masa pandemi. Hal ini menjadi dugaan alasan profitabilitas tidak berpengaruh terhadap TPE di tahun 2019.

Tahun 2020 terjadi lonjakan penerimaan pendapatan perusahaan kesehatan yang disebabkan oleh pandemi. Tabel 1 menunjukkan rata-rata rasio profititabilitas $10.44 \%$ sedangkan di tahun sebelumnya hanya $8 \%$. Akan tetapi, tidak adanya pengaruh profitabilitas terhadap tarif pajak efektif di tahun 2020 diduga adanya penundaan pendapatan. Penundaan diduga dilakukan akibat munculnya windfall tax, yaitu keuntungan tidak terduga yang dialami oleh suatu sektor tertentu terjadi sehingga menghasilkan pendapatan yang tidak terduga. Windfall tax terjadi akibat pandemi Covid19 yang mewabah di Indonesia.

Erawati dan Jega (2019) dan Nindita et al. (2021) dalam penelitiannya menghasilkan simpulan bahwa profitabilitas memberikan pengaruh signifikan negatif terhadap tarif pajak efektif. Perbedaan dengan penelitian ini dan penelitian-penelitian sebelumnya diduga pada perbedaan sektor perusahaan yang diteliti yang pada penelitian sebelumnya dilakukan terhadap sektor manufaktur. Perusahaan manufaktur cenderung berkembang lebih pesat dibandingkan dengan perusahaan kesehatan yang baru mulai bertumbuh sekarang ini.

Hipotesis 4: Pengaruh leverage terhadap tarif pajak efektif. Berdasarkan hasil uji hipotesis, leverage berpengaruh terhadap tarif pajak efektif di tahun 2020. Hasil pengujian salaras dengan penelitian (Pertiwi et al., 2016) dan (Juliani, 2019) yang menunjukkan bahwa leverage memengaruhi tarif pajak efektif secara positif. Walaupun hasil hipotesis tidak diterima karena menduga pengaruh negatif, leverage memiliki pengaruh terhadap tarif pajak efektif di masa saat pandemi tengah berlangsung. Peningkatan rata-rata leverage di tahun 2020 cukup signifikan bahkan sampai memiliki porsi lebih besar dibandingkan ekuitas perusahaan yaitu sebesar 1.0022543 berdasarkan Tabel 1. Menurut (Erawati dan Jega, 2019), penggunaaan utang diputar sebagai modal dan dimanfaatkan untuk investasi bukan kegiatan operasional sehingga cenderung meningkatkan pendapatan yang berasal dari luar operasional perusahaan. Hal ini menyebabkan tingginya utang yang dimiliki akan menyebabkan tarif pajak efektif perusahaan yang tinggi pula. 
(Indrawati, 2020) menyatakan dalam penelitiannya bahwa DER di dalam perusahaan farmasi tidak umum dipergunakan sebagai faktor pengambilan keputusan, sehingga besar kecilnya DER tidak berpengaruh terhadap variabel terikat. Hasil ini sejalan dengan hasil uji tahun 2019 bahwa leverage tidak berpengaruh terhadap tarif pajak efektif berbeda dengan penelitian-penelitian sebelumnya yang menjadi acuan penulisan.

Hipotesis 5: Pengaruh kepemilikan manajerial terhadap tarif pajak efektif. Kepemilikan manajerial berpengaruh signifikan negatif terhadap tarif pajak efektif pada tahun 2019 dan tidak berpengaruh pada tahun 2020. Jajaran manajemen yang memiliki sebagian saham perusahaan akan menjadi lebih termotivasi untuk meningkatkan kinerja perusahaan demi keuntungan dirinya sendiri yang juga selaras dengan kepentingan pemilik saham lainnya. Peningkatan kinerja juga dimanfaatkan untuk menekan beban pajak, karena beban tersebut akan mengurangi pendapatan perusahaan. Alasan tersebut diduga menjadi faktor pengaruh signifikan variabel struktur kepemilikan manajemen terhadap tarif pajak efektif. Hal ini sejalan dengan penelitian Erawati dan Jega (2019) yang menyatakan bahwa kepemilikan manjerial memberikan pengaruh terhadap tarif pajak efektif, walaupun dengan nilai signifikansi yang berbeda.

Hasil hipotesis tahun 2020 yaitu kepemilikan manajerial tidak berpengaruh terhadap tarif pajak efektif juga sejalan dengan (Syamsuddin dan Trisni, 2019) yang menyatakan kepemilikan publik tidak memiliki pengaruh signifikan terhadap tarif pajak efektif di masa pandemi. Hal ini diduga karena menurunnya nilai rata-rata kepemilikan perusahaan oleh manajemen berdasarkan Tabel 1 dan 2 . Walaupun hanya turun sekitar $2 \%$, hal ini dapat berpengaruh karena minat investor terhadap perusahaan sektor kesehatan di masa pandemi sehingga diduga terdapat beberapa manajemen yang melepas kepemilikan sahamnya untuk pihak lain. Hal ini selaras dengan grafik pada Gambar I.2 yang menunjukkan bahwa pertumbuhan penjualan saham perusahaan IDXHealth meningkat semenjak pandemi Covid-19 melanda.

Hipotesis 6: pengaruh kepemilikan publik terhadap tarif pajak efektif. Struktur kepemilikan publik berpengaruh signifikan negatif terhadap tarif pajak efektif pada tahun 2019 sedangkan kepemilikan publik pada tahun 2020 tidak berpengaruh terhadap tarif pajak efektif. Tata kelola yang tidak seimbang tersebut membuat kepemilikan publik tidak memiliki pengaruh sebesar kepemilikan manajerial dalam memutuskan kebijakan perusahaan. Manajer juga cenderung lebih agresif dalam memanfaatkan pembiayaa perusahaan dibandingkan dengan publik sehingga beban pajak dapat ditekan. Hal ini menjadi faktor kepemilikan publik berpengaruh negatif terhadap tarif pajak efektif. Pengaruh negatif ini menurut (Puspita dan Harto, 2014) disebabkan oleh kecilnya porsi kepemilikan saham yang dimiliki publik secara keseluruhan.

Sedangkan di tahun 2020 saat pandemi, kepemilikan publik tidak berpengaruh terhadap tarif pajak efektif. Nilai rata-rata struktur kepemilikan publik di tahun 2019 dan 2020 cenderung mirip. Perbedaan ini diduga akibat struktur kepemilikan saham yang lebih variatif akibat banyaknya minat investor terhadap kepemilikan saham perusahaan sektor kesehatan.

Hipotesis H7: perbandingan tarif pajak efektif. Penurunan tarif pajak efektif diduga bersumber dari kelonggaran (tax benefit) yang diberikan pemerintah dalam mengatasi 
pandemi, seperti penurunan tarif pajak badan di Perpu Nomor 1 Tahun 2020, insentif PPN dan PPh pasal 22 pada PMK239/PMK.03/2020 dan pemberian fasilitas pajak terhadap barang dan jasa yang diperlukan saat pandemi pada PMK143/PMK.03/2020. Tax benefit ini diduga dapat menurunkan TPE perusahaan sektor kesehatan. Namun pada kenyataannya TPE mengalami peningkatan di tahun 2020 dibandingkan 2019. Hal ini konsisten dengan peningkatan pendapatan pada tabel 1 dan 2 yang menunjukkan tingkat profitabilitas di tahun 2019 hanya 8\% sedangkan tahun 2020 naik menjadi $10 \%$.

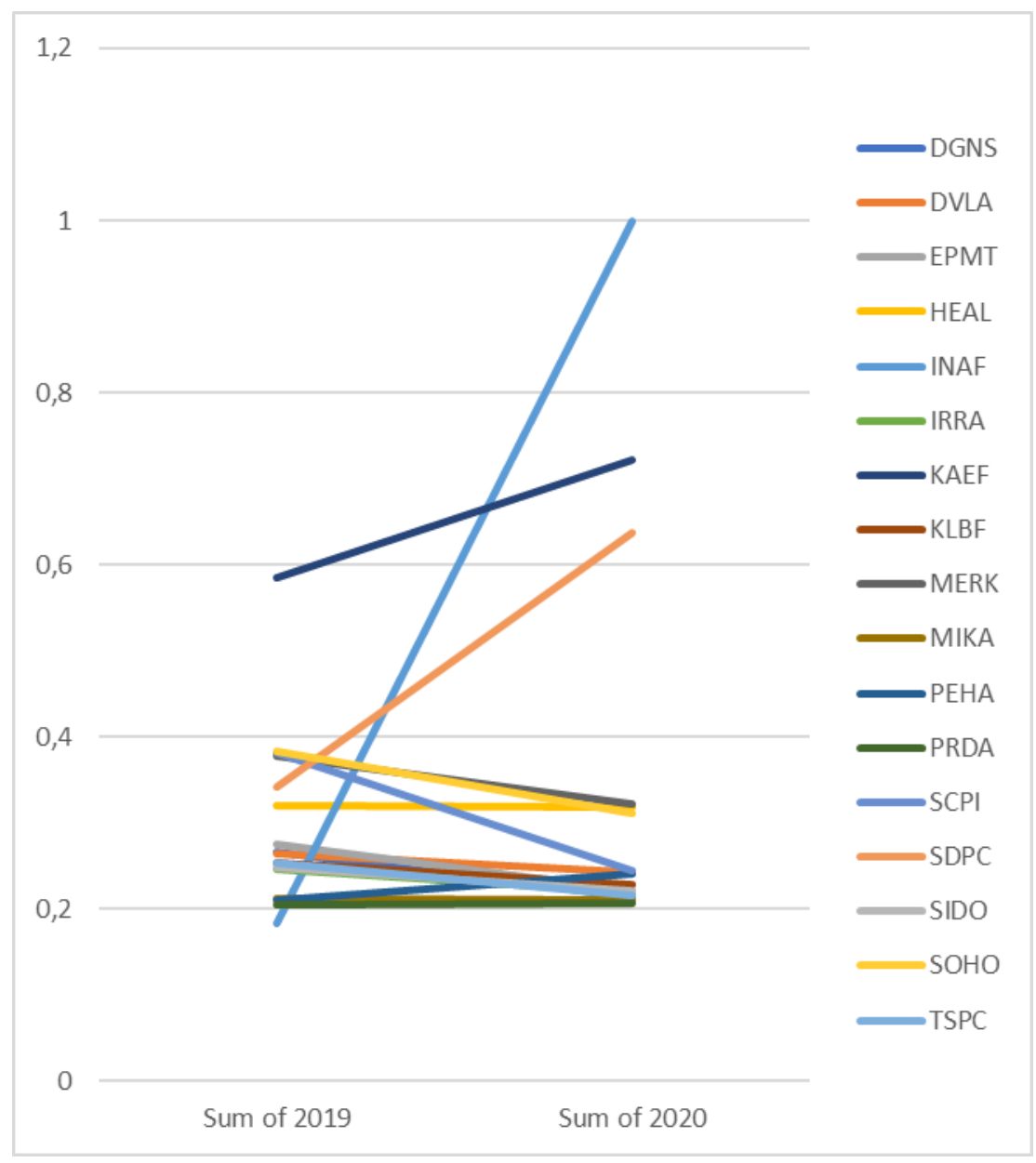

Gambar 3. Grafik Perbandingan Tarif Pajak Efektif Tiap Perusahaan Tahun 2020 dan 2019

Gambar 3 menunjukkan rata-rata perusahaan mengalami peningkatan tarif pajak efektif. Hasil ini juga dibuktikan dengan penelitian oleh (Welley et al., 2021) yang menunjukkan adanya kenaikan harga saham perusahaan farmasi BUMN akibat pandemi. Sentimen positif itu berdampak secara langsung terhadap perusahaan farmasi dengan peningkatan saham tersebut sampai $200 \%$ yang diakibatkan dari penemuan dan pengembangan vaksin. Pengaruh peraturan pengenaan pajak yang berlaku di Indonesia seperti Pasal 31E UU PPh yang memberikan fasilitas pengurangan pajak sebesar 50\% juga menjadikan tarif pajak efektif perusahaan bersifat lebih variatif. Selain itu menurut (Prasetya, 2019), selain banyaknya perusahaan kesehatan yang mengalami pendapatan, 
terdapat perusahaan yang pendapatannya cenderung sedikit menurun namun masih tetap stabil dan ada pula perusahaan yang memiliki kendala perpajakan dari tahun sebelumnya sehingga mengakibatkan beban pajak di tahun 2020 justru meningkat.

\section{KESIMPULAN}

Berdasarkan penelitian yang telah dilakukan, kesimpulan yang dapat diambil bahwa tarif pajak efektif pada perusahaan sektor kesehatan mengalami peningkatan di tahun 2020 saat pandemi mulai mewabah dibandingkan tahun sebelumnya. Terdapat perbedaan faktor-faktor yang memengaruhi tarif pajak efektif sebelum dan saat pandemi Covid-19. Transaksi hubungan istimewa yang diukur dengan piutang dan utang hubungan istimewa terhadap aset menunjukkan bahwa variabel bebas ini tidak berpengaruh terhadap tarif pajak efektif baik di tahun 2020 dan 2019.Variabel bebas profitabilitas juga tidak memiliki pengaruh terhadap tarif pajak efektif di tahun 2020 dan 2019 berbeda dengan penelitian-penelitian sebelumnya. Tidak adanya pengaruh profitabilitas terhadap tarif pajak efektif diduga nilai profit yang sangat fluktuatif di tahun penelitian akibat perkembangan sektor kesehatan.

Pada tahun 2020, leverage dengan proksi debt-equity ratio berpengaruh secara positif terhadap tarif pajak efektif sedangkan di tahun 2019, leverage tidak berpengaruh terhadap tarif pajak efektif. Leverage diduga meningkatkan tarif pajak efektif karena digunakan sebagai modal investasi sehingga justru meningkatkan pendapatan yang turut berdampak pada kenaikan tarif pajak. Struktur kepemilikan baik manajerial dan publik di tahun 2019 berpengaruh negatif terhadap tarif pajak efektif, sedangkan di tahun 2020 kedua variabel tidak berpengaruh terhadap tarif pajak efektif. Kepemilikan manajerial dan publik berpengaruh negatif di tahun 2019 karena manajer cenderung lebih agresif dalam mengelola perpajakan perusahaan dibandingkan dengan pemilik saham publik.

Variabel-variabel pengujian yang tidak berpengaruh berbeda dengan penelitianpenelitian sebelumnya yang menunjukkan adanya pengaruh transaksi hubungan istimewa dan profitabilitas terhadap tarif pajak efektif. Hal ini diduga karena penelitian dilakukan terhadap sektor kesehatan yang baru mulai bertumbuh di masa sekarang sementara penelitian sebelumnya kebanyakan dilakukan terhadap sektor manufaktur dan industri barang konsumsi. Secara simultan seluruh faktor berpengaruh terhadap tarif pajak efektif baik pada tahun 2019 dan 2020.

\section{DAFTAR PUSTAKA}

Darmadi, I. N. H., dan Zulaikha. (2013). Analisis Faktor yang Mempengaruhi Manajemen Pajak dengan Indikator Tarif Pajak Efektif (Studi Empiris Pada Perusahaan Manufaktur yang Terdaftar di Bursa Efek Indonesia pada Tahun 2011-2012). Diponegoro Journal of Accounting, 2(4), 368-379.

Darussalam, Septriadi, D., dan Kristiaji, B. B. (2013). Transfer Pricing Ide, Strategi, dan panduan praktis dalam Prespektif Pajak Internasional.

Erawati, T., dan Jega, B. Y. (2019). Pengaruh Ukuran Perusahaan, Tingkat Utang, Return on Asset (ROA) Terhadap Tarif Pajak Efektif pada Perusahaan Manufaktur yang Terdaftar di Bursa Efek Indonesia (BEI) (Studi Kasus pada Perusahaan Manufaktur 
BEI pada Periode Tahun 2016-2018). Jurnal Ilmiah Akuntansi Dan Humanika, 9(3), 247-255.

Fransiska, dan Lestari, J. S. (2014). Pengaruh Transaksi Pihak-Pihak Istimewa terhadap Kinerja Keuangan Perusahaan. Jurnal Ekonomi Akuntansi, 5(2), 107-117.

Gita, I. A. M. A., Partika, I. D. M., and Suciwati, D. P. (2021). Effect Firm Size, Profitability and Inventory Intensity Against Effective Tax Rate (ETR). Journal of Applied Sciences in Accounting, Finance, and Tax, 4(1), 9-15. https://doi.org/10.31940/jasafint.v4i1.2410.

Indradi, D., dan Setyahadi, M. M. (2019). Pengaruh Transaksi Hubungan Istimewa terhadap Tarif Pajak Efektif dengan Leverage sebagai Variabel Moderating. Jurnal Akuntansi Berkelanjutan Indonesia, 2(3), 375-392.

Indrawati, M. (2020). Pengaruh Kinerja Keuangan dan Makro Ekonomi terhadap Harga Saham selama Pandemi Covid-19 pada Perusahaan Sub Sektor Farmasi.

Juliani, S. (2019). Pengaruh Ukuran Perusahaan, Leverage, Profitabilitas, dan Komisaris Independen terhadap Manajemen Pajak dengan Indikator Tarif Pajak Efektif (Studi Pada Perusahaan Industri Sektor Barang Konsumsi Yang Terdaftar dalam BEI Periode 2013-2018).

Kim, K. A., and Limpaphayom, P. (1998). Taxes and firm size in pacific-basin emerging economies. Journal of International Accounting, Auditing and Taxation, 7(1), 47-68. https://doi.org/10.1016/S1061-9518(98)90005-2.

Nilasari, A., dan Setiawan, I. (2019). Pengaruh Good Corporate Governance dan Transaksi Hubungan Istimewa Terhadap Effective Tax Rate (Studi Empiris pada Perusahaan Manufaktur Yang Terdaftar Di Bursa Efek Indonesia Tahun 2013-2017). Jurnal Renaissance, 4(02), 583-598.

Nindita, F. K., Rahman, A., dan Rosyafah, S. (2021). Pengaruh Debt to Equity Ratio, Return on Assets, Related Party Transaction terhadap Penghindaran Pajak. UBHARA Accounting Journal, 1(2), 418-428.

Oktavia, Subagyo, dan Kristanto, S. B. (2012). Transaksi hubungan istimewa dan pengaruhnya terhadap tarif pajak efektif perusahaan. Jurnal Akuntansi, 12(2, November 2012), 701-716.

Pertiwi, K., Manik, T., dan Husna, A. (2018). Pengaruh Intensitas Modal, Leverage, Intensitas Persediaan, Transaksi Perusahaan Afiliasi, dan Transfer Pricing Terhadap Tarif Pajak Efektif pada Perusahaan Manufaktur yang terdaftar di Bursa Efek Indonesia Tahun 2013-2016.

Prasetya, V. (2019). Analisis Kinerja Keuangan Perusahaan Sebelum Dan Saat Pandemi Covid 19 Pada Perusahaan Farmasi Yang Tercatat Di Bursa Efek Indonesia. Jurnal Bisnis Dan Manajemen, 5(2), 579-587. https://doi.org/10.26905/jbm.v5i2.2664.

Sabrinna, A. I. (2019). Pengaruh Corporate Governance dan Struktur Kepemilikan Terhadap Kinerja Keuangan Perusahaan. https://doi.org/10.21776/ub.profit.2019.013.02.1

Sambuari, I. B., Saerang, I. S., dan Maramis, J. B. (2020). Reaksi Pasar Modal Terhadap Peristiwa Virus Corona (Covid-19) Pada Perusahaan Makanan Dan Minuman Yang Terdaftar Di Bursa Efek Indonesia. JMBI UNSRAT (Jurnal Ilmiah Manajemen Bisnis Dan Inovasi Universitas Sam Ratulangi), 7(2), 407-415. https://doi.org/10.35794/jmbi.v7i3.30668. 
Sarwoasih, S., dan Indarto. (2018). Analisis Pengaruh Profitabilitas Likuiditas dan Pertumbuhan Perusahaan Terhadap Kebijakan Utang serta Dampaknya Terhadap Tarif Pajak Efektif. Jurnal Riset Ekonomi Dan Bisnis, 11(1), 22. https://doi.org/10.26623/jreb.v11i1.1075.

Soepriyanto, G. (2011). Faktor-Faktor yang Mempengaruhi Variasi Tarif Pajak Efektif Perusahaan: Studi Terhadap Perusahaan yang Terdaftar di BEI Tahun 2002 - 2006. Binus Business Review, 2(2), 1025. https://doi.org/10.21512/bbr.v2i2.1244.

Sugiyono. (2019). Metode Penelitian Kuantitatif, Kualitatif, dan R\&D. Penerbit Alfabeta, Bandung.

Susilawaty, T. (2020). Analisis Faktor-faktor yang Mempengaruhi Tarif Pajak Efektif pada Perusahaan Food and Beverage yang Terdaftar di Bursa Efek Indonesia.

Syamsuddin, M., \& Trisni, S. (2019). Pengaruh Intensitas Modal, Intensitas Persediaan, Komisaris Independen dan Kepemilikan Manajerial Terhadap ETR. Dinamika Akuntansi, Keuangan Dan Perbankan, 8(2), 158-168.

Welley, M. M., Oroh, F. N. S., dan Walangitan, M. D. (2021). Perbandingan Harga Saham Perusahaan Farmasi Bumn Sebelum Dan Sesudah Pengembangan Vaksin Virus Corona (Covid-19). JMBI UNSRAT (Jurnal Ilmiah Manajemen Bisnis Dan Inovasi Universitas Sam Ratulangi)., 7(3), 571-579. https://doi.org/10.35794/jmbi.v7i3.31514

Yudawirawan, Moh. Y., Yanuar, Y., dan Hamdy, S. (2021). Pengaruh Tata Kelola Perusahaan dan Transfer Hubungan Istimewa terhadap Tarif Pajak Efektif Perusahaan. SCIENTIFIC JOURNAL OF REFLECTION: Economic, Accounting, Management and Business, 4(2), 139-148.

Republik Indonesia. 2008. Undang-undang Nomor 36 Tahun 2008 tentang Perubahan Keempat atas Undang-undang Nomor 7 Tahun 1983 Tentang Pajak Penghasilan.

Republik Indonesia. 2020. Peraturan Pemerintah Pengganti Undang-Undang Republik Indonesia Nomor 1 Tahun 2020 tentang Kebijakan Keuangan Negara dan Stabilitas Sistem Keuangan untuk Penanganan Pandemi Corona Virus Disease 2019 (Covid-19) dan/atau dalam Rangka Menghadapi Ancaman yang Membahayakan Perekonomian Nasional dan/atau Stabilitas Sistem Keuangan.

Kementerian Keuangan Republik Indonesia. Peraturan Menteri Keuangan Republik Indonesia Nomor 22/PMK.03/2020 tentang Tata Cara Pelaksanaan Kesepakatan Harga Transfer (Advance Pricing Agreement).

Kementerian Perindustrian Republik Indonesia. Buku Analisis Pembangunan Industri Edisi - II 2021, Membangun Kemandirian Industri Farmasi Nasional.

Direktorat Jenderal Pajak. Laporan Kinerja Direktorat Jenderal Pajak 2020.

Ikatan Akuntansi Indonesia. 2014. PSAK No. 7 yang Mengatur Tentang Pengungkapan Pihak-pihak Berelasi-edisi revisi 2014. Jakarta.

Satuan Tugas Penanganan Covid. https://covid19.go.id/.

Andayani, Tri Juniati. (21 Februari 2021). Covid-19 Bertahan, Insentif Pajak Dilanjutkan. Situs Resmi Direktorat Jenderal Pajak. https://www.pajak.go.id/id/artikel/covid-19bertahan-insentif-pajak-dilanjutkan (diakses tanggal 27 Mei 2021).

Sandy, Ferry. (18 November 2020). Nah Lho! Ribuan Restoran di DKI Tutup Permanen. CNBC Indonesia. https://www.cnbcindonesia.com/news/20201118124932-4202716/nah-lho-ribuan-restoran-di-dki-tutup-permanen. (diakses tanggal 21 Mei 2021). 
Santoso, Yusuf Iman. (6 Januari 2021). Ini penyebab shortfall penerimaan pajak tahun

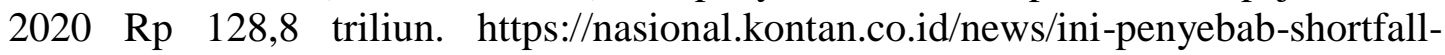
penerimaan-pajak-tahun-2020-rp-1288-triliun. (diakses tanggal 19 Agustus 2021). 